Гордана Арсић-Комљеновић ${ }^{1}$, Драган Микић², Јелена Кенић ${ }^{3}$ Христо Анђелски ${ }^{4}$

\title{
CONSEQUENCES OF STRESS AT THE LEVEL OF CELLS
}

Gordana Arsić-Komljenović, Dragan Mikić, Jelena Kenić, Hristo Anđelski

\section{Сажсетак}

Организам представља јединствен, специчфичан, мултицелуларни, мултимолекулски, динамичан и високо организован систем који је у сталном садејству са факторима животне средине, а у исто време представља и отворен термодинамички систем кроз који се врии стални проток и промет материје и трансформачија енергије. Сви ти сложени процеси и интеракиије су под контролом генома и фактора животне средине. Данас је све евидентније да организам представља јединствено тројство: мозак-тело-геном, а ови ентитети интерагују између себе. У юима се одигравају врло сложени генски, интегрисани и регулисани процеси из којих резултирају све животне функиије, почев од размножавања, раста, прежсивљавања и старења, па до адаптаџије организма на нагле промене у животној средини, тј. стрес. Поремећаји у интегрисаним функиијама ових система доводе до дубоких промена у хомеостази организма у целини и до испољавања штетних последица стреса на нивоу ћелија и организма. (Каназир и сар, 2004)

Кључне речи: стрес, неуроендокрини одговор.

\section{Summary}

The organism is a unique, specific, multicellular, multimolecular, dynamic and highly organized system that is in constant interaction with environmental factors, and at the same time represents a thermodynamically open system which is done through a constant flow of traffic and transformation of matter and energy. All these complex processes and interactions are controlled by the genome and environmental factors. Today more and more evident that the organism is a unique trinity: mind-body-genome, and these entities interact with each other. They occur very complex gene, integrated and regulated processes resulting from whom all life functions, ranging from proliferation, growth, survival and aging, and the adaptation of the organism to sudden changes in the environment, i.e. stress. Disorders in the integrated functions of these systems lead to profound changes in the homeostasis of the organism as a whole, and to the appearance of the harmful consequences of stress at the level of cells and organisms. (Kanazir et al., 2004)

Key words: stress, neuroendocrine response.

\footnotetext{
${ }^{1}$ Проф. др мед. Гордана Арсић-Комљеновић, Висока медицинска школа струковних студија „Милутин Миланковић“, Београд.

2 Др мед. Драган Микић, Војномедицинска академија, Београд.

${ }^{3}$ Мр мед. Јелена Кенић, „Richter Gedeon“ д.о.о, Београд.

${ }^{4}$ Проф. др мед. Христо Анђелски, Висока медицинска школа струковних студија „Милутин Миланковић“, Београд.
} 
$\mathrm{C}$ тресна стања могу бити акутна и хронична, а дужина трајања стресног стања зависи од природе стресора и од интензитета одговора организма на стрес, односно од психо-неуроимуног стања организма (Каназир и сар, 2004).

Описујући општи адаптациони синдром код експерименталних животиња, Сели је утврдио да га увек прате исти патоанатомски налази (хипертрофија надбубрежне жлезде, атрофија тимуса и акутне лезије желуца или стрес улкуси) (Selye, 1980).

У одговор на стресне стимулусе укључене су мултипле мождане структуре, од којих је најважнији хипоталамус. Са друге стране, сигнали из хипоталамуса се преносе на хипофизу, а из њих на друге системе. Најважнија последица ефекта стреса је активација неуроендокрине осовине хипоталамус-хипофиза-надбубрежна жлезда и активација система ренин-ангиотензин. Типични неуроендокрини одговор обухвата иницијално, унутар секунде повећање секреције катехоламина (адреналина и норадреналина) из симпатичког нервног система и медуле надбубрега, ослобађање CRH и вазопресина из парвоцелуларних неурона у портну циркулацију, повећање секреције окситоцина из неурохипофизе и 5-10 секунди касније секрецију АСТН из хипофизе. Овај одговор такође обухвата смањење секреције гонадотропина и повећање секреције пролактина и хормона раста из предњег режња хипофизе, повећање секреције ренина из бубрега и панкреасну секрецију глукагона. Неколико минута касније повећава се ниво глукокортикоида у плазми, а инхибише се секреција стероида гонада. Ипак, глукокортикоидни пик се јавља између 30 минута и 1 сата након дејства стресора (Sapolsky и сар, 2000).

Организам се од атака стреса „брани““ својим механизмима, стањем адаптације или покушаја задржавања равнотеже или хомеостазе. Алостаза је стање адаптације на стрес, односно покушај поновног успос- тављања хомеостазе. Стање умерене алостазе има позитиван ефекат на организам (Bruce и сар, 2003).

Исхемија, као најважнији фактор стреса, доводи до оксидативних оштећења ћелија; она се манифестују повећаном пероксидацијом липида мембрана, порастом у концентрацији оксидисаних протеина и консеквентно у значајним променама у транспорту и путевима трансдукције сигнала (Каназир и сар, 2004).

Екстрацелуларни извори реактивних врста кисеоника (ROS) створених током исхемије могу значајно оштетити спољну страну ендотелних ћелија крвних судова кардиоваскуларног система; са друге стране, реперфузија, повратак на нормалну концентрацију кисеоника у крви, може због повећења инфлукса калцијума пореметити унутар ћелије механизме регулације оксидо-редуктивног баланса и на тај начин довести до интрацелуларног оштећења. Нагомилавање полиморфонуклеарних леукоцита у лезији је праћено отпуштањем деривата ROS-a. Леукоцити поред генерисања ROS-a такође излучују екстрацелуларно лизозомалне ензиме који имају изразито цитотоксично дејство; на тај начин се даље поспешује ткивно оштећење и запаљенски процес (Č olić и сар, 1999).

Бројни подаци показују да су иницијација и прогресија патогенезе разних обољења изазваних стресом последица поремећаја у трансдукцији сигнала унутар ћелија и експресији стресом активираних гена (Bosта и сар, 1998).

Могуће је закључити да сигнали стреса делују на ћелију преко мембранских или интрацелуларних рецептора, који затим преносе сигнале стреса унутар ћелије и на тај начин активирају бројне ензиме из фамилије фосфопротеинских киназа и/ или транскрипционе факторе (Bosma и сар, 1998).

Активација транскрипционих фактора затим доводи до промене експресије појединих специфичних гена. Наведене про- 
мене у експресији гена финално доводе до одговарајућих метаболичких промена у ћелији, које представљају адаптациони механизам, односно одговор ћелије на деловање стреса. Међутим, одговор на стрес је генетски предетерминисан, па се може рећи да су све фазе ћелијског одговора, тј. индукција стресног одговора, његова модулација, као и регистровање интензитета стреса и дужина трајања, барем једним делом, генетски предетерминисани процеси (Liu и сар, 1999).

У условима стреса, као што је више пута речено, у организму долази до повећане продукције катехоламина, стероида, посебно глукокортикоида и слободних радикала, а они директно или индиректно делују на механизме регулације концентрације калцијума у ћелији. Јон калцијума игра значајну улогу, јер везујући се за молекул протеина (ензима) стабилизује његову терцијерну структуру. Регулација поменутих животних процеса зависи од укупне количине интрацелуларног калцијума. Када интрацелуларна концентрација калцијума постане неконтролисана и када дође до неконтролисане акумулације калцијума у ћелији, онда се покрећу механизми који могу да доведу до смрти ћелије (Кажић и сар, 1997).

У вишећелијском организму постоји функционална међузависност ћелија, ткива и органа, те патолошко догађање у једној ћелији, ткиву или органу не остаје изоловано. Оштећење ћелија и ткива и следствено нарушавање хомеостазе активира ћелијске механизме, чији је крајњи ефекат неутрализација штетних молекула и опоравак захваћених функција. Природно то захтева додатни „напор“ ћелијског метаболизма и могуће предефинисање приоритета, што често може даље да погорша ове виталне процесе (Спужић, 1998). Према томе, исход оштећења ћелије може да буде њен опоравак или њена смрт. Овако дихотомно постављање проблема представља крајње поједностављивање сложених догађања која се дешавају у ћелији.
Смрт је могући исход оштећења ћелије (Спужић, 1998; Бумбаширевић и сар, 1998).

Колико год ова концепција описивала задесну смрт, изазвану снажним агенсом који тренутно уништава неки или све аспекте ћелије, толико је она погрешна када се говори о програмираној ћелијској смрти, апоптози. У основи реч је о извршењу сложеног генетског програма, за шта је потребна синхронизација читавог низа метаболичких процеса (Glucksmann, 1959). Дакле, ћелијска смрт може да се препозна у виду бар два различита морфолошка елемента, апоптозе и некрозе. Данас се верује да су апоптоза и некроза само исказ два екстрема једног истог процеса (Спужић, 1998).

Ћелијске промене у току стреса се могу посматрати и са аспекта апоптозе. Апоптоза представља контролисан начин ћелијског умирања у коме ћелија активно учествује, спроводи прецизан генски регулисан програм аутодеструкције, тј. ћелијског „суицида“" (Маjno и сар, 1995). За испољавање овог процеса понекад је неопходна активна синтеза макромолекула, а ћелијске органеле дуго остају очуваног интегритета. Апоптоза је комплементаран процес митози, и координација та два процеса одређује одржавање ћелијског састава или ћелијску атрофију. Апоптоза такође представља механизам за елиминацију „непожељних“ ћелија, као што су оштећене, преканцерске или прекобројне ћелије (Wyllie и сар, 1980). Поремећај овог процеса може бити у основи пролиферације пренеопластичних и неопластичних ћелија, или настанку неуродегенеративних болести, аутоимуних обољења, а вероватно и болести изазваних стресом (Thompson, 1995; Cho и сар, 2003).

Апоптоза, дефинисана као скуп морфолошких и биохемијских карактеристика програмиране ћелијске смрти (Marti и сар, 1998), може бити индукована у многим типовима ћелија бројним физиолошким, биохемијским и/или „штетним” нефизиолошким стимулусима, а разликује се од патолошке форме ћелијске смрти некрозе 
(Schwatzman и cap, 1993). Некрозом умиру ћелије услед наглог оштећења као код исхемије, физичке или хемијске трауме (Cohen, 2003). У некрози, постоје ране промене облика и функције митохондрија; плазма мембрана губи способност регулације осмотског притиска, ћелија бубри, долази до руптуре мембране и изливања интрацелуларног садржаја у околину.

Апоптозом се уклањају ћелије продуковане у вишку, неправилно развијене ћелије или оне које носе генетска оштећења (Thompson, 1995). У најранијим ступњевима ембрионалног развоја апоптоза се јавља као значајан механизам за обликовање будућег организма, што се огледа кроз формирање органа, замену једне врсте ткива другом и ресорпцију привремених органа (Umansky, 1996).

Најраније промене у току апоптозе које се могу уочити светлосним микроскопом укључују: смањење волумена ћелије, тј. кондензацију, промене у облику ћелије, односно заокруживање, затим појаву бројних продужетака који на крајевима садрже органеле и најзад кондензовање хроматинског материјала (Trump и сар, 1997). Карактеристичне промене огледају се у кондензацији и фрагментацији једра (Umansky, 1996).

Већина интрацелуларних органела остаје непромењена, иако митохондрије постају кондензоване, а ендоплазматски ретикулум дилатиран. У иницијалној фази, апоптотична ћелија губи контакт са суседним ћелијама у ткиву, а касније долази до ћелијске фрагментације. Фрагменти окружени мембраном који садрже органеле и остатке једра названи су „апоптотска тела”. У in vivo условима апоптотска тела подлежу процесу фагоцитозе од стране макрофага и суседних ћелија, чиме се спречава цурење потенцијално штетног материјала и накнадно оштећење ткива (Fesus и сар, 1991; Umansky, 1996). У тим условима апоптотска тела највероватније лизирају, тако да се ова терминална фаза in vitro ћелијске смрти назива „секундарна” некроза (Trump и сар,
1997). Процес апоптозе може бити веома брз, јер ћелије које се подвргну апоптози могу комплетно нестати у року од 4 сата (Wyllie и саp, 1980; Fesus и сар, 1991).

Основна биохемијска карактеристика апоптозе је активација ендонуклеаза и фрагментација DNK, што се узима као дефинитиван апоптотски маркер (Schwatzman и сар, 1993). Прво се продукују већи, а потом мањи фрагменти DNK (Walker и сар, 1993). Природа нуклеаза које секу нуклеарну DNK ћелије у апоптози није у потпуности утврђена. Постоје подаци о $\mathrm{Ca}^{2+}$, $\mathrm{Mg}^{2+}$ зависним ендонуклеазама попут нпр. NУC18, изолованих из апоптотичних тимоцита третираних глукокортикоидима, а неки аутори указују на улогу DNK-аза I и II у овом процесу (Umansky, 1996). Међутим, неки аутори наводе да фрагментација није обавезан процес у току апоптозе, јер и ануклеиране ћелије подлежу апоптози (Umansky, 1996).

Сматра се да је апоптоза активан процес који захтева метаболичку енергију, као и RNK и протеинску синтезу (Fesus и сар, 1991). Протеинска синтеза и генска активност имају значајну улогу у апоптози, јер инхибитори RNK и протеинске синтезе могу спречити настанак морфолошких и биохемијских промена у апоптози (Mesner и сар, 1997). Апоптотска смрт индукована у таргет ћелијама посредством цитотоксичних лимфоцита или ћелија природних убица није супримирана агенсима који инхибирају протеинску синтезу; шта више, индукција апоптозе преко TNF (tumor necrosis factor) или CD95 рецептора је олакшана инхибицијом синтезе протеина или RNK. Ова чињеница указује на постојање две класе протеина у апоптози, агонисте и антагонисте, тако да је исход, ћелијска смрт или преживљавање, одређен превладавањем једног система над другим (Umansky, 1996).

Сам процес апоптозе може се поделити на три фазе: фазу индукције, фазу окидања или сензорне реакције и егзекуције (Green и сар, 1995; Vaux и сар, 1996). 
Фаза индукције подразумева иницијални догађај или сигнал који покреће процес апоптозе у ћелији, и то спољашњи сигнал доспео преко површинских рецептора или може долазити из саме ћелије услед дејства неког агенса. Најбитнији механизам индукције апоптозе је изазивање оштећења DNK, изазваног дејством физичких агенаса ( $\gamma$ или UV zračenja), DNK алкилације (под утицајем цитостатских лекова), променама у активности топоизомеразе II и дејством реактивних кисеоничних врста (ROS).

Следећа фаза укључује детекцију овог сигнала или метаболичког стања и одлуку ћелије да ли ће се подврћи апоптози. Та од- лука је под контролом бројних, различитих путева трансдукције сигнала, које сматрамо интрацелуларним сензорима иницијалних стимулуса, тј. окидачима централног механизма. Ови централни догађаји који у ствари доводе до смрти ћелије подразумевају се под концептом егзекуције (Green и cap, 1995). Централну улогу у извршењу програма ћелијске смрти имају протеазе (цистеин - протеазе или „циспазе”), које су укључене у индукцију и трансдукцију овог процеса. Четврта фаза ћелијске смрти је постмортем фаза, у којој се ћелијски хроматин кондензује и фрагментише DNK (Vaux и сар, 1996).

\section{ЛИТЕРАТУРА}

1. Bosma H, Peter R, Siegrist J, Marmot M. Two alternative job stress models and risk of coronary heart disease. Am. J. Public Health 1998; 8868-74.

2. McEwen B, Norton Lashley E. The End of Stress as We Know It. Nature Medicine 2003; 6: 640-648.

3. Бумбаширевић В, Богдан Ђ, Молекулске основе оштећена, репараџије и смрти ћелије. Српска академија наука и уметности, Медицинска академија Српског лекарског друштва. Београд, 1998; 5-24.

4. Cho $\mathrm{CH}, \mathrm{Wu} \mathrm{KK}, \mathrm{Wu} \mathrm{S}$, Wong $\mathrm{TM}$, So WH, Liu ES, Chu KM, Shin VY, Ye YN, Wong BC. Morphine as a drug for stress ulcer prevention and healing in the stomach. Eur $\mathrm{J}$ Pharmaco. 2003; 460: 177-182.

5. Cohen S, Hamrick N. Stable individual differences in physiological response to stressors: impilcations for stress-elicited changes in immune related health. Brain Behav Immun 2003; 17(6): 407-414.

6. Čolić M, Gašić S, Vasilijić S, Pejanović V, Jandrić D, Medić-Mijačević LJ, Rakić

Lj. A nucleoside analogue, 7-thia-8oxogunaosine stimulates proliferation of thymocytes in vitro. Immunol Lett 1999; 69: 293-300.

7. Fesus L, Davies PJ, Piacentini M. Apoptosis: Molecular mechanisms in programmed cell death. Europian Journal of Cell Biology. 1991; 56: 170-177.

8. Glucksmann A. Celldeaths in normal vertebrate ontogeny. Biol. Rev. Camb Philos Soc 1959; 26: 59-86.

9. Green DR, Martin S. The killer and the executioner: How apoptosis controls malignancy. Current Opinion in Immunology. 1995; 7: 694-703.

10. Каназир С, Пајовић Б, Радојчић М. Б, Молекуларни механизми стресом индукованих обољења кардиоваскуларног система. САНУ, посебна издања: Књига 3 , Одељење хемијских и биолошких наука, Београд, 2004.

11. Kažić T, Zdravković M, Klinička kardiovaskularna farmakologija. Beograd, 1997.

12. Liu J, Mori A. Stress, Aging, and Brain Oxidative Damage. Neurochem. Res. 1999; 1479-1497. 
13. Liu J, Li ZS, Wan XJ, Wang W.

Expression and function of apoptosisrelated genes Bcl-2/Bax and Fas/Fas L in the course of stress ulcer. Neurochem. Res. 2003; 83(6): 504-509.

14. Majno G, Joris I. Apoptosis, oncosis and necrosis. Am. J. Pathol 1995:146:3-15.

15. Mesner PW, Budiharardjo II, Kaufman SH. Chemotherapy - induced apoptosis. Advances in Pharmacology. 1997; 41: 461-499.

16. Sapolsky RM, Romero LM, Munck AU. How do glucocorticoids influence stress responses? Integrating permissive, suppressive, stimulatory, and preparative actions. Endocr. Rev. 2000; 21: 55-89.

17. Sapolsky RM. Stress hormones: good and bad. Neurobiol. Dis. 2000; 7: 540-542.

18. Schwartzaman RA, Cidlowsky JA. Endocrine Reviews. 1993; 14: 133-151.

19. Selye H. The evolution of the stress concept. Am. Scient. 1973; 61: 692-699.

20. Selye H. ed. Selyes Guide to Stress Research, Vol. 1. Van Nostrand Reinhold, New York, 1980.

21. Спужић И, Молекулске основе оштећена, репарације и смрти ћелије.
Српска академија наука и уметности, Београд 1998; 1-4.

22. Thompson BC. Apoptosis in the pathogenesis and treatment of disease. Science. 1995; 267: 1456-1462.

23. Steller H. Mechanisms and genes of cellular suicide. Science. 1995; 267: 14451449.

24. Trump BF, Berezesky IK, Seung HC, Phelps PC. The pathways of cell death: oncosis, apoptosis and necrosis. Toxicology Pathology. 1997; 25(1): 82-88.

25. Umansky SR. Apoptosis: Molecular and cellular mechanisms (A Re-view). Molecular Biology. 1996; 30(3): 285-295.

26. Vaux DL, Strasser A. The molecular biology of apoptosis. Proceedings of National Academy of Science. 1996; 93 : 2239-2244.

27. Walker PR, Kokileva L, LeBlanc J, Sikorska M. Detection of the ini-tial stages of DNA fragmentation in apoptosis. Bio Techniqes. 1993; 15: 6.

28. Wyllie AH, Kerr JFR, Curt AR. Cell death: the significance of apoptosis. Int. Rev. Cytol 1980; 68: 251-306.

Контакт: Др мед. Гордана Арсић-Комљеновић, Висока медицинска школа струковних студија „Милутин Миланковић“, Црнотравска 27, Београд. 